\title{
The nutritional value of raw, autoclaved and dehulled peas (Pisum sativum L.) in chicken diets as affected by enzyme supplementation
}

\author{
A. Brenes ${ }^{1}$, B. A. Rotter ${ }^{2}$, R. R. Marquardt, and W. Guenter \\ Department of Animal Science, University of Manitoba, Winnipeg, Manitoba, Canada R3T 2 N2. \\ Received 6 November 1992, accepted 31 March 1993.
}

\begin{abstract}
Brenes, A., Rotter, B. A., Marquardt, R. R. and Guenter, W. 1993. The nutritional value of raw, autoclaved and dehulled peas (Pisum sativum $\mathrm{L}$.) in chicken diets as affected by enzyme supplementation. Can. J. Anim. Sci. 73: $605-614$. The effects of added crude enzyme preparations, autoclaving and dehulling on the nutritional value of diets containing a low-tannin (Trapper) and high-tannin (Maple) cultivar of peas (Pisum sativum L.) for chicks were determined in four experiments. The addition of crude enzymes from different sources and at different concentrations to a diet containing $75 \%$ of the low-tannin peas did not improve chick performance (exp. 1). Similarly, no improvement in performance was observed when a combination of crude enzymes was added to the diet containing whole or dehulled low-tannin peas, (exp. 2). Autoclaved treatment and enzyme addition to the diet containing the high-tannin Maple peas improved $(P<0.05)$ the feed-to-gain ratio but not the weight gain (exp. 3). Autoclaving or dehulling improved the apparent metabolizable energy ( 21 vs. $30 \%)$ and apparent protein digestibility (11 vs. $15 \%$ ) of the high-tannin peas, respectively, in contrast to the low-tannin peas (experiment 4). Dehulling improved the feed-to-gain ratio of chickens fed both cultivars of peas. In conclusion, the results indicate that addition of crude enzymes to diets containing raw or dehulled lowtannin peas do not improve the chick performance but improve the feed efficiency of chicks when fed with the high-tannin peas. Autoclaving and dehulling improved the apparent metabolizable energy and protein digestibility values of high-tannin Maple peas while dehulling improved the feed-to-gain ratio of both cultivars.
\end{abstract}

Key words: Crude enzyme, peas, chick, metabolizable energy, dehulling, autoclaving

Brenes, A., Rotter, B. A., Marquardt, R. R. et Guenter, W. 1993. Effet d'un complément enzymatique sur la valeur nutritive des pois (Pisum sativum L.) crus autoclavés et dépelliculés pour les poulets. Can. J. Anim. Sci. 73: 605-614. Les effets de l'adjonction d'une préparation enzymatique brute ainsi que de l'autoclavage et du dépelliculage ont été déterminés en quatre expériences sur la valeur nutritive de régimes alimentaires contenant un cultivar de pois à basse teneur (Trapper) et un cultivar à forte teneur (Maple) en tanins. L'adjonction de diverses préparations enzymatiques brutes à différentes concentrations, à un régime fait pour $75 \%$ de pois à basse teneur en tanins n'a pas amélioré les performances des poulets (expérience 1). On n'a pas non plus noté d'amélioration à la suite de l'apport d'un mélange d'enzymes brutes à un régime contenant des pois à basse teneur en tanins entiers ou dépelliculés (expérience 2). Par ailleurs, l'autoclavage et la complémentation enzymatique du régime contenant le pois à forte teneur en tanins ont apporté une amélioration $(P<0,05)$ de l'indice de consommation, mais pas du gain de poids (expérience 3). L'autoclavage ou le dépilliculage ont amélioré l'ćnergie métabolisable apparente (respectivement, par 21 et 30\%) et la digestibilité apparente des proétines par 11 et $15 \%$ ) des pois à forte teneur en tanins, par rapport au pois à basse teneur en tanins. Le dépelliculage a amélioré l'indice de consommation des poulets pour les deux cultivars de pois. Il ressort

\footnotetext{
${ }^{1}$ Present address (A.B.): Consejo Superior de Investigaciones Cientificas. Instituto de Alimentacion Animal. Ciudad Universitaria, 28040 Madrid, Spain.

${ }^{2}$ Present address (B.R.): Centre for Food and Animal Research, Agriculture Canada, K.W. Neatby Bldg. CEF, Ottawa, Ontario, Canada KIA 0C6.
} 
de ces observations que l'adjonction de préparations enzymatiques brutes à des régimes contenants des pois à basse teneur en tanins crus ou dépelliculés n`a pas amélioré les performances des poulets, mais l'indice de consommation était amélioré quand le traitement portait sur des pois à forte teneur en tanins. L'autoclavage et le dépelliculage ont relevé les valeurs d'énergie métabolisable et de digestibilité des protéines pour le pois à forte teneur en tanins cependant que le dépelliculage améliorait l'indice de consommation des deux cultivars.

Mots clés: Préparation enzymatique brute, pois, poulet, énergie métabolisable, dépelliculage, autoclavage

Peas (Pisum sativum L.) are used as livestock feed in many parts of the wold. In recent years peas have been used as alternative protein supplements for imported soybean meal. The use of peas in the diets of growing chickens has been documented (Moran et al. 1968; Davidson 1980; Larbier and Blum 1981; Vogt 1983). Raw peas may contain inhibitors that could lead to poor utilization by humans and monogastric animals (Savage 1988). Enzymes have been extensively used in the past decade as additives to poultry diets (Campbell and Bedford 1992). Numerous studies have demonstrated the benefits of crude enzyme preparations when added to barley-containing diets (Suga et al. 1978; Hesselman et al. 1981; White et al. 1981; Classen et al. 1985; Rotter et al. 1990). Castanon and Marquardt (1989) examined the effects of enzyme supplementation on the utilization of legume seeds and observed no major improvements in chick performance. Compared with wheat, peas had a high percentage of carbohydrates which are poorly digested by adult cockerels (Longstaff and McNab 1986, 1987). This poor digestibility may be attributed in part to the size and nature of the starch granules or accessibility of the starch granules to enzyme attack which is dependent on the endosperm cell wall thickness and structure. Longstaff and McNab (1987) suggested that the lower starch digestibility was due to the complex mixture of polysaccharides including oligosaccharides (Saini 1988; Trevino et al. 1990). The complex polysaccharide mixture in peas was partially digested by cellulase and amylase (Longstaff and McNab 1987) which indicates that there is scope for improving the nutrient availability from peas for poultry. To investigate this possibility further, several studies were conducted: (1) to identify cell-walldegrading enzyme supplements that will most effectively improve chick performance when added to diets containing low-tannin (Trapper) and high-tannin (Maple) pea cultivars, with peas being the major protein supplement; and (2) the metabolizable energy values of the raw, autoclaved and dehulled peas were also determined in this study.

\section{MATERIALS AND METHODS}

\section{General Procedures}

The experimental diets were formulated to meet or exceed the minimum National Research Council requirements for Single Comb White Leghorn and broiler chicks (NRC 1984). All diets were given in mash form and the birds had free access to water and feed throughout the experiment. The pea cultivars used in this study were Trapper (white flower, low-tannin) and Maple (coloured flower, high-tannin) grown in Manitoba (Canada). The crude enzyme preparations and their activities (as determined by the manufacturer) used in the studies were: Energex (a cell-wall-degrading multi-enzyme complex that contained hemicellulase, $150000 \mathrm{U}$ $\mathrm{g}^{-1}$; pectinase $10000 \mathrm{U} \mathrm{g}^{-1} ; \beta$-glucanase, $75 \mathrm{U}$ $\mathrm{g}^{-1}$; and endoglucanase, $400 \mathrm{U} \mathrm{g}^{-1}$ ) hydrolyzes a broad range of carbohydrates and was produced from selected strain of Aspergillus niger), Bio-Feed Pro (proteolytic enzyme produced from selected strain of Bacillus licheniformis that contained 150000 endoproteinase $\mathrm{U} \mathrm{g}^{-1}$ ) and Novozym SP-230 (contained $500 \mathrm{U} \mathrm{g}^{-1}$ of $\alpha$-galactosidase activity) all from NOVO (Novo Nordisk $\mathrm{A} / \mathrm{S}$, Bagsvaerd, Denmark), Cellulase Tv (Miles Laboratories Inc., Elkhart, IN 46515) concentrate (from a controlled fermentation of Trichoderma viride) contained 23880 cellulase $\mathrm{U} \mathrm{g}^{-1}$, and 
$\alpha$-amylase (Sigma Chemical Co., St. Louis, MO 63178) (Sigma Grade VI).

One-day-old male Leghorn and broiler chicks (Arbor-Acre/Ross parentage) were purchased from a commercial hatchery and raised in Jamesway (James Mfg. Co., Mount Joy, PA) battery brooders. All chicks were fed commercial chick starter crumbles $(21 \%$ protein) during the $7-\mathrm{d}$ preexperimental period. At $7 \mathrm{~d}$ of age, the birds were randomly assigned to the different diets (Tables 1 and 2) in Petersime (Petersime Incubator Co., Gettysburg, $\mathrm{OH} 45328$ ) battery brooders. Experiments 1-3 were conducted for $14 \mathrm{~d}$. The birds were weighed and feed consumption was determined on days 14 (7-14 d) and 21 (14-21 d). Chick performance was measured in terms of feed consumption, weight gain and feed-to-gain ratio and the overall values were reported for each experiment on a per-bird basis.

\section{Experiment 1}

A total of 432 leghorn chicks were randomly distributed among nine treatments using six birds per pen and eight pen replicates per treatment to determine the effect of addition of three different crude enzyme preparations (Energex, Bio-Feed Pro, Cellulase Tv) and amylase and their combinations to a pea-based diet on the performance of leghorn chicks (Table 1). The treatments were as follows: (1) corn-pea control diet (CP); (2) CP plus $0.1 \%$ Energex; (3) CP plus 0.3\% Energex; (4) $\mathrm{CP}$ plus $0.1 \%$ Bio-Feed Pro; (5) CP plus 0.3\% BioFeed Pro; (6) CP plus $0.1 \%$ Energex plus $0.1 \%$ Bio-Feed Pro; (7) CP plus 0.1\% Cellulase Tv; (8) CP plus $0.3 \%$ Cellulase Tv and (9) CP plus $0.1 \%$ each of Energex, Bio-Feed Pro and Amylase.

\section{Experiment 2}

A total of 144 broiler chicks were randomly distributed among four treatments using six birds per pen and six pen replicates per treatment to evaluate the effect of enzyme addition to a whole and dehulled pea-diet on the performance of broiler chicks (Table 1). The dietary treatments were arranged as $2 \times 2$ factorial: (1) corn-whole Trapper peas (CWT); (2) CWT plus $0.1 \%$ each of Energex,

Table 1. Composition of experimental diets (exps. 1 and 2), percent

\begin{tabular}{|c|c|c|c|}
\hline \multirow[b]{2}{*}{ Ingredients } & \multirow{2}{*}{$\frac{\text { Experiment } 1}{\text { Trapper peas }}$} & \multicolumn{2}{|c|}{ Experiment 2} \\
\hline & & Trapper peas & Dehulled Trapper peas \\
\hline Corn & 11.34 & 7.92 & 7.92 \\
\hline Peas $^{2}$ & 75.00 & 70.00 & - \\
\hline Dehulled peas" & - & - & 64.18 \\
\hline Soybean concentratey & 2.50 & 8.00 & 8.00 \\
\hline Tallow & 6.25 & 9.10 & 9.10 \\
\hline Dicalcium phosphate & 1.15 & 1.30 & 1.30 \\
\hline Calcium carbonate & I. .43 & 1.60 & 1.60 \\
\hline DL-methionine & 0.18 & 0.43 & 0.43 \\
\hline Vitamins $^{x}$ & 1.00 & 1.00 & 1.00 \\
\hline Minerals ${ }^{\mathrm{w}}$ & 0.35 & 0.35 & 0.35 \\
\hline Chromic oxide & 0.30 & - & - \\
\hline $\begin{array}{l}\text { Enzyme mix }{ }^{v} \\
\text { (added as a premix) }\end{array}$ & 0.50 & 0.50 & 0.50 \\
\hline Sand & - & - & 5.82 \\
\hline \multicolumn{4}{|l|}{ Calculated analysis } \\
\hline Protein $(\%)$ & 18.77 & 22.19 & 22.19 \\
\hline $\mathrm{ME}\left(\mathrm{MJ} \mathrm{kg}^{-1}\right)$ & 12.18 & 12.14 & 12.14 \\
\hline Lysine (\%) & 1.19 & 1.58 & 1.58 \\
\hline Meth. + Cyst. (\%) & 0.66 & 0.86 & 0.85 \\
\hline $\mathrm{Ca}(\%)$ & 0.80 & 0.90 & 0.90 \\
\hline P (\%) (available) & 0.40 & 0.45 & 0.45 \\
\hline
\end{tabular}

${ }^{\mathrm{z}}$ Trapper peas (protein $20.8 \%, \mathrm{~N} \times 6.25$ ) and dehulled Trapper peas (protein $23.35 \%$ ).

${ }^{y}$ Protein $84 \%$.

${ }^{x_{A}}$ Amount supplied $\mathrm{kg}^{-1}$ diet: vitamin A, $8250 \mathrm{IU}$, vitamin $\mathrm{D}_{3}, 991 \mathrm{IU}$, vitamin $\mathrm{E}, 11 \mathrm{IU}$; vitamin $\mathrm{B}_{12}, 11.5 \mu \mathrm{g}$; vitamin K, $1.1 \mathrm{mg}$; riboflavin, $5.5 \mathrm{mg}$; Ca-pantothenate. $11.0 \mathrm{mg}$; niacin, $53 \mathrm{mg}$; choline chloride, $1020 \mathrm{mg}$; folic acid, $0.75 \mathrm{mg}$; biotin, $0.25 \mathrm{mg}$; ethoxyquin, $125.0 \mathrm{mg}$.

"Amount supplied $\mathrm{kg}^{-1}$ diet: Mn, $55 \mathrm{mg}$; Zn, $50 \mathrm{mg}$ : Fe, $80 \mathrm{mg}$; Cu, $5 \mathrm{mg}$; Se, $0.1 \mathrm{mg}$;, $0.18 \mathrm{mg}$ : $\mathrm{NaCl}, 2.5 \mathrm{~g}$.

'Amount and type of enzyme added is given in Materials and Methods. 


\begin{tabular}{|c|c|c|c|c|}
\hline \multirow[b]{3}{*}{ Ingredients } & \multirow{3}{*}{$\begin{array}{l}\text { Experiment } 3 \\
\text { Maple peas }\end{array}$} & \multicolumn{3}{|c|}{ Experiment 4} \\
\hline & & \multirow[b]{2}{*}{ Basal } & \multicolumn{2}{|c|}{ Peas } \\
\hline & & & Trapper & Maple \\
\hline Corn & 13.57 & 64.34 & - & - \\
\hline Peas ${ }^{2}$ & 75.00 & 30.00 & 95.00 & 95.00 \\
\hline Sunflower oil & 6.50 & - & - & - \\
\hline Dicalcium phosphate & 1.15 & 2.20 & 1.06 & 1.06 \\
\hline Calcium carbonate & 1.43 & 1.00 & 1.82 & 1.82 \\
\hline DL-methionine & 0.20 & 0.31 & 0.47 & 0.47 \\
\hline Vitamins ${ }^{y}$ & 1.00 & 1.00 & 1.00 & 1.00 \\
\hline Minerals $\mathrm{x}$ & 0.35 & 0.35 & 0.35 & 0.35 \\
\hline Enzyme mix ${ }^{w}$ & 0.50 & 0.50 & 0.50 & 0.50 \\
\hline \multicolumn{5}{|l|}{ Calculated analysis } \\
\hline Protein (\%) & 19.37 & 20.10 & 19.76 & 22.90 \\
\hline ME (MJ kg ${ }^{-1}$ ) & 12.13 & 12.20 & - & - \\
\hline Lysine $(\%)$ & 1.23 & 1.11 & 1.52 & 1.56 \\
\hline Meth. + Cyst. $(\%)$ & 0.60 & 0.90 & 0.86 & 0.85 \\
\hline $\mathrm{Ca}(\%)$ & 0.80 & 0.82 & 0.85 & 0.85 \\
\hline P (\%) (available) & 0.40 & 0.59 & 0.45 & 0.45 \\
\hline
\end{tabular}

${ }^{2}$ Trapper (protein 20.8\%) and Maple (protein 24.11\%).

${ }^{y_{S}}$ Same as Table 1.

'Same as Table 1.

"Amount and type of enzyme added is given in Materials and Methods.

Bio-Feed Pro and Novozym; (3) corn-dehulled Trapper peas diet (CDT); (4) CDT plus the same combination of enzymes as in treatment 2 . The dehulled diets contained sand to replace the hull. Seeds were dehulled with the aid of a roller and the hull fraction was removed by air classification.

\section{Experiment 3}

A total of 144 cockerels were randomly distributed among four treatments $(2 \times 2$ factorial $)$ as follows: (1) corn-raw Maple peas diet (CRM); (2) CRM plus $0.1 \%$ each of Energex, Bio-Feed Pro and Novozym; (3) corn-autoclaved Maple peas diet (CAM); and (4) CAM plus the same combination of enzymes as treatment 2 to determine the effect of a combination of enzymes (Energex, Bio-Feed Pro and Novozym) on the performance of leghorn chicks fed whole raw and autoclaved Maple peas. The control diet is given in Table 2 .

\section{Experiment 4}

Two hundred and sixteen broiler chicks were randomly distributed among nine treatments using four birds per pen and six replicates per treatment to determine the nitrogen corrected apparent metabolizable energy $\left(\mathrm{AME}_{\mathrm{n}}\right)$ of two cultivars (Trapper and Maple) raw, autoclaved and dehulled peas. Autoclaving involved the use of pea meal which was spread to a depth of approximately $1 \mathrm{~cm}$ on stainless steel pans and heated to $121^{\circ} \mathrm{C}$ for $20 \mathrm{~min}$ in a standard laboratory sterilizer. The seeds were dehulled as described in exp. 2. The treatments were as follows: (1) corn-soy basal diet (CS); (2) Trapper peas basal diet (TP); (3) Maple peas basal diet (MP); (4) CS plus TP diet (50:50 mixture); (5) CS plus MP diet (50:50); (6) CS plus autoclaved Trapper peas diet; (7) CS plus autoclaved Maple peas diet (50:50); (8) CS plus dehulled Trapper peas diet (50:50) and (9) CS plus dehulled Maple peas diet (50:50). The composition of the diets is given in Table 2. All chicks were fed commercial chick starter crumbles $(21 \%$ protein) during the 10-d pre-experimental period. The comparative balance trial (10-17 d of age; chromic oxide indicator at $0.3 \%$ ) consisted of a 4 -d pretrial (adaptation) and a 3-d collection period. Feed consumption, weight gain and feed-to-gain ratio were also determined in this period.

\section{Chemical Analyses}

The pea cultivars (Trapper and Maple) were analyzed for chemical composition prior to diet formulation. Samples of whole and dehulled peas and hulls were analyzed for dry matter (DM), protein $\left(\mathrm{N}_{2} \times 6.25\right)$, fat (ether extract) ash, calcium and phosphorus by standard methods (Association of 
Official Analytical Chemists (AOAC) 1984). Neutral detergent fibre (NDF) and acid detergent fibre (ADF) were determined using a refluxing apparatus (Laboratory construction Col. Kansas City, MO) according to procedures outlined by Van Soest and Wine (1967); the NDF procedure was modified to exclude use of decalin and sodium sulfite (Mascharenhas Ferreira et al. 1983). Starch was analyzed after gelatinization and enzymatic hydrolysis using thermostable $\alpha$-amylase (Novo, Coppenhagen, Denmark) and amyloglucosidase (Boehringer, Germany) according to the procedure of Aman and Hesselman (1984). Amino acids were determined according to the procedures outlined by Andrews and Baldar (1985) with performic acid oxidation of cystine and methionine according to Hirs (1967). Final analysis was carried out on a
LKB 4151 Alpha Plus Amino Acid Analyzer (LKB Biochron Ltd., Cambridge Science Park, Cambridge, UK) equipped with an LKB 4029 Programmer and a 3393A Hewlett-Packard Integrator (Hewlet-Packard Co., Avondale, PA 19311). Feed and excreta samples were analyzed for gross energy using a Parr adiabatic oxygen bomb calorimeter (Parr Instrument Co., Moline, IL 61265). Nitrogen was determined using the Kjeldahl procedure as described in Association of Official Analytical Chemists (AOAC 1984) and chromic oxide was analyzed according to Williams et al. (1962). In addition, excreta samples were analyzed for uric acid content (Marquardt 1983) and the apparent protein digestibility (APD) was calculated as described by Rotter et al. (1989). The procedure used for $\mathrm{AME}_{\mathrm{n}}$ determination was as

\begin{tabular}{|c|c|c|c|c|c|c|}
\hline & \multicolumn{6}{|c|}{ Pea cultivar } \\
\hline & \multicolumn{3}{|c|}{ Trapper } & \multicolumn{3}{|c|}{ Maple } \\
\hline & Whole & Dehulled & Hulls & Whole & Dehulled & Hulls \\
\hline Dry matter $(\%)$ & 90.62 & 92.46 & 94.23 & 91.55 & 92.36 & 92.93 \\
\hline Protein (\%) & 20.80 & 23.35 & 4.55 & 24.11 & 25.86 & 4.72 \\
\hline Fat $(\%)$ & 1.18 & 1.03 & 0.31 & 0.80 & 0.84 & 0.04 \\
\hline $\operatorname{ADF}(\%)$ & 6.40 & 2.16 & 63.74 & 7.75 & 1.83 & 57.63 \\
\hline $\operatorname{NDF}(\%)$ & 14.24 & 12.87 & 71.60 & 17.01 & 11.35 & 60.77 \\
\hline Ash (\%) & 2.74 & 2.80 & 3.11 & 2.80 & 2.87 & 2.86 \\
\hline $\mathrm{Ca}(\%)$ & 0.07 & 0.03 & 0.44 & 0.09 & 0.04 & 0.42 \\
\hline $\mathrm{P}(\%)$ & 0.30 & 0.32 & 0.05 & 0.31 & 0.44 & 0.06 \\
\hline Starch $(\%)$ & 40.31 & 46.48 & Trace & 39.48 & 46.34 & Trace \\
\hline Hull $(\%)$ & 8.31 & - & - & 9.71 & - & - \\
\hline Tannin (\%) & & & 0.11 & - & - & 6.83 \\
\hline \multicolumn{7}{|l|}{ Amino acid (\%) } \\
\hline Alanine & 0.93 & 1.00 & 0.19 & 0.98 & 1.05 & 0.21 \\
\hline Arginine & 1.87 & 2.01 & 0.17 & 2.37 & 2.46 & 0.22 \\
\hline Aspartic acid & 2.58 & 2.75 & 0.70 & 2.88 & 3.17 & 0.60 \\
\hline Cystine & 0.17 & 0.17 & 0.02 & 0.16 & 0.18 & 0.00 \\
\hline Glutamic acid & 3.87 & 4.20 & 0.42 & 4.20 & 4.57 & 0.47 \\
\hline Glycine & 0.98 & 1.05 & 0.23 & 1.03 & 1.10 & 0.24 \\
\hline Histidine & 0.51 & 0.55 & 0.08 & 0.55 & 0.60 & 0.10 \\
\hline Isoleucine & 0.74 & 0.83 & 0.14 & 0.39 & 0.86 & 0.16 \\
\hline Leucine & 1.52 & 1.65 & 0.27 & 1.63 & 1.75 & 0.30 \\
\hline Lysine & 1.59 & 1.71 & 0.27 & 1.64 & 1.81 & 0.29 \\
\hline Methionine & 0.19 & 0.20 & 0.04 & 0.19 & 0.20 & 0.04 \\
\hline Phenylalanine & 1.08 & 1.12 & 0.19 & 1.09 & 1.17 & 0.20 \\
\hline Proline & 0.94 & 1.01 & 0.18 & 1.00 & 1.04 & 0.18 \\
\hline Serine & 1.11 & 1.16 & 0.22 & 1.15 & 1.22 & 0.23 \\
\hline Threonine & 0.82 & 0.87 & 0.17 & 0.85 & 0.90 & 0.18 \\
\hline Tyrosine & 0.62 & 0.62 & 0.12 & 0.65 & 0.68 & 0.11 \\
\hline Valine & 0.87 & 0.97 & 0.17 & 1.93 & 1.00 & 0.20 \\
\hline Ammonia & 0.17 & 0.18 & 0.03 & 0.19 & 0.20 & 0.04 \\
\hline
\end{tabular}


outlined by Rotter et al. (1990). Total phenolic content (tannin) in hulls was determined by the Folin-Dennis method as described by Burns (1963).

\section{Statistical Analysis}

All experiments were set up as completely randomized designs and data were subjected to analysis of variance using the General Linear Models (GLM) Procedure of the Statistical Analysis System, Institute, Inc. (1986) program. Experiments 2 and 3 were analyzed as $2 \times 2$ factorial arrangements of treatments. Selected linear contrasts of interest among various variables were made within the analysis of variance and used for mean comparison. Only contrasts that were significant are presented in the tables.

\section{RESULTS}

The composition of the two pea cultivars (Trapper and Maple) and their dehulled (cotyledon) and hulled (testa) fractions was similar (Table 3); however, compared with whole seeds, dehulled seeds were generally richer in protein, amino acids and starch and had less ADF and NDF. Hulls, in contrast, generally had low protein, amino acids and starch contents and very high concentrations of ADF and NDF and Ca. The tannin contents of the two cultivars differed greatly $(0.11$ and $6.83 \%$ for Trapper and Maple, respectively).

The results of the feeding trial in exp. 1 demonstrate that none of the crude enzyme preparations produced beneficial responses when added to the diet containing pea (Table 4). The enzyme mixtures, except in a few cases, tended to reduce feed intake and weight gain but not feed-to-gain ratio. The addition of Energex to the diet, for example, significantly reduced weight gain $(P=0.02)$ and feed consumption $(P=0.001)$ but not the feedto-gain ratio $(P>0.05)$ (contrast 1 vs. 2,3 ). In exp. 2, the addition of a combination of enzymes (Energex, Bio-Feed Pro and Novozym) to the diet containing whole or dehulled Trapper peas also resulted in a reduction $(P=0.05)$ in feed consumption but not $(P>0.05)$ weight gain or the feed:gain ratio (Table 5). The diet containing dehulled peas plus sand produced performance values the same as those obtained when the diet contained whole peas $(P>0.05)$. In exp. 3 (Table 6), the high-tannin Maple pea variety was subjected to autoclaving and enzyme treatments using the same combination of enzymes as used in exp. 2. Small but significant reductions in feed consumption $(P=0.001)$ and weight gain

\begin{tabular}{|c|c|c|c|}
\hline Treatments & $\begin{array}{l}\text { Weight gain } \\
\text { (g) }\end{array}$ & $\begin{array}{c}\text { Feed consumption } \\
(\mathrm{g})\end{array}$ & $\begin{array}{l}\text { Feed-to-gain } \\
\text { ratio } \\
\end{array}$ \\
\hline 1 No enzymes & 116 & 271 & 2.35 \\
\hline 2 Energex $0.1 \%$ & 109 & 258 & 2.38 \\
\hline 3 Energex $0.3 \%$ & 108 & 249 & 2.32 \\
\hline 4 Bio-Feed Pro $0.1 \%$ & 110 & 258 & 2.34 \\
\hline 5 Bio-Feed Pro $0.3 \%$ & 117 & 270 & 2.31 \\
\hline 6 Energex + BioFeed Pro $(0.1 \%$ each) & 106 & 254 & 2.39 \\
\hline 7 Cellulase Tv $0.1 \%$ & 116 & 275 & 2.38 \\
\hline 8 Cellulase Tv $0.3 \%$ & 114 & 260 & 2.29 \\
\hline 9 Energex + Bio-Feed Pro + Amylase $(0.1 \%$ each $)$ & 111 & 257 & 2.32 \\
\hline SEM & 2.5 & 4.3 & 0.04 \\
\hline Treatment contrast & \multicolumn{3}{|c|}{$P$ values } \\
\hline 1 vs 2,3 & 0.022 & 0.001 & 0.900 \\
\hline 1 vs. $3,5,8$ & 0.308 & 0.024 & 0.857 \\
\hline $2,4,7$ vs. $3,5,8$ & 0.611 & 0.213 & 0.063 \\
\hline 2,3 vs. 4,5 & 0.055 & 0.017 & 0.618 \\
\hline 2,3 vs 7,8 & 0.015 & 0.002 & 0.717 \\
\hline (7-8) vs. (4-5), interaction & 0.084 & 0.003 & 0.452 \\
\hline
\end{tabular}


Table 5. Performance of broiler chicks (7-21 d) fed enzyme supplemented raw and dehulled Trapper peas (exp. 2) ${ }^{\mathrm{Z}}$

\begin{tabular}{lccc}
\hline & $\begin{array}{c}\text { Weight } \\
\text { gain } \\
\text { Treatments }\end{array}$ & $\begin{array}{c}\text { Feed } \\
\text { consumption } \\
(\mathrm{g})\end{array}$ & $\begin{array}{c}\text { Feed-to-gain } \\
\text { ratio }\end{array}$ \\
\hline No enzyme & 408 & 609 & 1.50 \\
+ enzyme & 382 & 568 & 1.45 \\
SEM & 7.6 & 14.2 & 0.02 \\
$P$ value & 0.169 & 0.054 & 0.091 \\
\hline
\end{tabular}

${ }^{\mathrm{z}}$ There was no interaction $(P>0.05)$ between enzyme treatment (diets with or without added enzyme) and dehull treatment (diets with whole or dehulled peas). There was also no difference between dehulled and whole peas $(P>0.05)$.

${ }^{y}$ Energex $0.1 \%+$ Bio-Feed Pro $0.1 \%+$ Novozym $0.1 \%$.

Table 6. Performance of leghorn chicks (7-21 d) fed enzyme supplemented raw or autoclaved Maple peas (exp. 3)

\begin{tabular}{|c|c|c|c|}
\hline Treatments & $\begin{array}{l}\text { Weight } \\
\text { gain } \\
\text { (g) }\end{array}$ & $\begin{array}{c}\text { Feed } \\
\text { consumption } \\
(\mathrm{g})\end{array}$ & $\begin{array}{c}\text { Feed-to-gain } \\
\text { ratio }\end{array}$ \\
\hline \multicolumn{4}{|l|}{ Peas (P) } \\
\hline Raw & 116 & 241 & 2.08 \\
\hline Autoclaved & 113 & 228 & 2.03 \\
\hline \multicolumn{4}{|l|}{ Enzyme (E) } \\
\hline No $E$ & 114 & 237 & 2.08 \\
\hline$+E^{z}$ & 115 & 232 & 2.03 \\
\hline SEM & 1.6 & 3.4 & 0.02 \\
\hline Factor & \multicolumn{3}{|c|}{$P$ values } \\
\hline $\mathrm{P}$ & 0.037 & 0.001 & 0.021 \\
\hline $\mathrm{E}$ & 0.573 & 0.219 & 0.009 \\
\hline$P \times E$ & 0.122 & $0.036^{y}$ & 0.381 \\
\hline $\begin{array}{l}{ }^{\mathrm{z}} \mathrm{E}=\text { Energex } \\
0.1 \% \text {. } \\
{ }^{\mathrm{y}} \text { Values for the } \\
\text { peas }+\mathrm{E}=23 \\
\text { peas }+\mathrm{E}=2\end{array}$ & $\begin{array}{l}\%+\mathrm{Bi} \\
\text { teraction } \\
\mathrm{g} \text {, autocl } \\
\mathrm{g} .\end{array}$ & $\begin{array}{l}\text { Feed Pro } 0.1 \\
\text { ere: raw pea } \\
\text { ed peas }=22\end{array}$ & $\begin{array}{l}+ \text { Novozym } \\
=247 \mathrm{~g}, \text { raw } \\
\mathrm{g}, \text { autoclaved }\end{array}$ \\
\hline
\end{tabular}

$(P=0.04)$ were observed in the chicks fed the autoclaved compared with those fed the raw pea diet. This treatment, however, improved the feed-to-gain ratio by $2 \%$ $(P=0.02)$. Enzyme addition to either the raw or autoclaved pea diet also improved the overall feed-to-gain ratio from 2.08 to 2.03
$(P=0.01)$ but did not affect $(P>0.05)$ feed consumption or weight gain. A pea $\times$ enzyme interaction $(P=0.04)$ indicated that adding enzyme to raw pea resulted in reduced feed consumption while no effect was observed for autoclaved peas.

Broiler chicks fed a high concentration $(95 \%)$ of Trapper or Maple peas had significantly $(P \leq 0.01)$ lower weight gains, increased feed-to-gain ratios $(P<0.01)$ and reduced APD $(P<0.01)$ compared with those fed the control corn-soybean diet (contrast 1 vs. 2, 3, Table 7). In addition, chicks fed the diet containing a high concentration of the tannin-free pea cultivar (Trapper) had significantly $(P<0.01)$ better feed-to-gain ratio (2.12 vs. 2.37$)$ and a higher APD (72 vs. $50 \%$ ) (contrast 2 vs. 3 ) than chicks fed a diet containing the high concentration of the tannin-containing pea cultivar (Maple). Feeding a mixed corn-soybean and pea diet (50:50) as raw peas, however, greatly improved chick performance yielding values comparable to those obtained with the cornsoybean basal diet (contrast 1 vs. 4, 5). A comparison among treatments for chicks fed the $50 \%$ pea-containing diets indicated that dehulling peas further improved the feed-togain ratio (1.70 for whole vs. 1.62 for dehulled peas $(P=0.02)$, contrast 4,5 vs. $8,9)$. There were also significant $(P<0.01)$ interactions between the cultivar of pea and autoclaved treatment (linear contrasts 4-5 vs. 6-7, interactions) and between the cultivar of pea and dehulling (linear contrast 4-5 vs. 8-9, interaction) for $\mathrm{APD}$ (Table 7) and $\mathrm{AME}_{\mathrm{I}}$ (Table 8). In these interactions, autoclave treatment or dehulling compared with the untreated control had very little effect on the APD of Trapper peas ( 83 or 80 vs. $81 \%$, respectively), but had a very marked effect on Maple peas ( 81 or 85 vs. $73 \%$, respectively). Similar results were also obtained with $\mathrm{AME}_{\mathrm{n}}$ values. The $\mathrm{AME}_{\mathrm{n}}$ value of Maple peas was considerably lower (8.14 vs. 9.16 $\mathrm{MJ} \mathrm{kg}^{-1}$ ) than that of Trapper peas. Autoclaving (9.88 $\left.\mathrm{MJ} \mathrm{kg}^{-1}\right)$ and dehulling $\left(10.60 \mathrm{MJ} \mathrm{kg}^{-1}\right.$ ) increased the $\mathrm{AME}_{\mathrm{n}}$ value of Maple peas but not that of Trapper peas. 
Table 7. Weight gains, feed consumption. feed efficiency and apparent protein digestibility (APD) of broiler chicks (10-17 d) fed various treatments of Trapper and Maple peas (exp. 4)

\begin{tabular}{|c|c|c|c|c|}
\hline Treatments & $\begin{array}{c}\text { Weight gain } \\
(\mathrm{g})\end{array}$ & $\begin{array}{l}\text { Feed consumption } \\
\text { (g) }\end{array}$ & $\begin{array}{l}\text { Feed-to-gain } \\
\text { ratio }\end{array}$ & $\begin{array}{l}\mathrm{APD} \\
(\%)\end{array}$ \\
\hline 1 Corn-soy basal (CS) & 193 & 319 & 1.65 & 83 \\
\hline 2 Trapper peas (TP) & 138 & 292 & 2.12 & 72 \\
\hline 3 Maple peas (MP) & 131 & 310 & 2.37 & 50 \\
\hline $4 \mathrm{CS}+\mathrm{TP}(50: 50)$ & 206 & 349 & 1.69 & 81 \\
\hline $5 \mathrm{CS}+\mathrm{MP}(50: 50)$ & 194 & 330 & 1.70 & 73 \\
\hline $6 \mathrm{CS}+$ autoclaved $\mathrm{TP}(50: 50)$ & 203 & 335 & 1.65 & 83 \\
\hline $7 \mathrm{CS}+$ autoclaved MP (50:50) & 197 & 333 & 1.69 & 81 \\
\hline $8 \mathrm{CS}+$ dehulled TP $(50: 50)$ & 201 & 336 & 1.67 & 80 \\
\hline $9 \mathrm{CS}+$ dehulled MP $(50: 50)$ & 205 & 323 & 1.58 & 85 \\
\hline SEM & 6.1 & 8.5 & 0.04 & 1.1 \\
\hline Treatment contrast & \multicolumn{4}{|c|}{$P$ values } \\
\hline 1 vs. 4 & NS & $<0.05$ & NS & NS \\
\hline 1 vs. 5 & NS & NS & 0.09 & $<0.01$ \\
\hline 2 vs. 3 & NS & NS & $<0.01$ & $<0.01$ \\
\hline 1 vs. 2,3 & $<0.01$ & 0.09 & $<0.01$ & $<0.01$ \\
\hline 1 vs. 4,5 & NS & 0.06 & NS & $<0.01$ \\
\hline 2,3 vs. 4,5 & $<0.01$ & $<0.01$ & $<0.01$ & $<0.01$ \\
\hline 4,5 vs. 6.7 & NS & NS & NS & $<0.01$ \\
\hline 4,5 vs. 8,9 & NS & NS & $<0.05$ & $<0.01$ \\
\hline (2-3) vs. (4-5) interaction & NS & $<0.05$ & NS & $<0.01$ \\
\hline (4-5) vs. (6-7) interaction & NS & NS & NS & $<0.01$ \\
\hline (4-5) vs. (8-9) interaction & NS & NS & 0.09 & $<0.01$ \\
\hline
\end{tabular}

Table 8. Apparent metabolizable energy $\left(\mathrm{AME}_{11}\right)$ of various treatments of Trapper (TP) and Maple (MP) peas (exp. 4)

\begin{tabular}{|c|c|c|}
\hline \multirow[b]{2}{*}{ Treatments } & \multicolumn{2}{|c|}{$\mathrm{AME}_{\mathrm{n}}\left(\mathrm{MJ} \mathrm{kg}{ }^{-1}\right)$} \\
\hline & Diet & Pea \\
\hline 1 Corn-soy basal (CS) & 11.90 & $\mathrm{NA}^{z}$ \\
\hline $4 \mathrm{CS}+\mathrm{TP}(50: 50)$ & 10.53 & 9.16 \\
\hline $5 \mathrm{CS}+\mathrm{MP}(50: 50)$ & 10.02 & 8.14 \\
\hline $6 \mathrm{CS}+$ autoclaved TP $(50: 50)$ & 10.52 & 9.14 \\
\hline $7 \mathrm{CS}+$ autoclaved MP $(50: 50)$ & 10.89 & 9.88 \\
\hline $8 \mathrm{CS}+$ dehulled TP $(50: 50)$ & 10.70 & 9.50 \\
\hline $9 \mathrm{CS}+$ dehulled MP $(50: 50)$ & 11.41 & 10.60 \\
\hline SEM & 0.12 & 0.24 \\
\hline Treatment contrast & \multicolumn{2}{|c|}{$P$ values } \\
\hline 1 vs. 4 & $<0.01$ & $\mathrm{NA}^{z}$ \\
\hline 1 vs. 5 & $<0.01$ & NA \\
\hline 4 vs. 5 & $<0.01$ & 0.011 \\
\hline 5 vs. 7 & $<0.01$ & $<0.01$ \\
\hline 5 vs. 9 & $<0.01$ & $<0.01$ \\
\hline l vs. 6,7 & $<0.01$ & NA \\
\hline l vs. 8,9 & $<0.01$ & NA \\
\hline 4,5 vs. 6.7 & $<0.01$ & $<0.01$ \\
\hline 4.5 vs. 8,9 & $<0.01$ & $<0.01$ \\
\hline (4-5) vs. (6-7) interaction & $<0.01$ & $<0.01$ \\
\hline (4-5) vs. (8-9) interaction & $<0.01$ & $<0.01$ \\
\hline
\end{tabular}

${ }^{\mathrm{z}_{\mathrm{NA}}}=$ not applicable.
The improvements in $\mathrm{AME}_{\mathrm{n}}$ following autoclaving and dehulling of Maple peas were 21 and $30 \%$, respectively, compared with the raw peas. Although the improvements for the complete diets were lower, the trends were similar to that calculated for peas alone.

\section{DISCUSSION}

The results obtained in this study and by other researchers (Vose et al. 1976; Savage and Deo 1989) indicate that the chemical composition of most pea cultivars may be similar except for the content of condensed tannins. The starch content (40.3\% Trapper and $39.5 \%$ Maple) and crude protein of the seeds $(20.8$ and $24.1 \%)$ are in good agreement with values commonly found in other cultivars (Institut National de la Recherche Agronomique 1984). Dehulling reduced the fiber content of peas and proportionately increased the concentration of other nutrients including protein and digestible carbohydrates. The modification in nutrient concentration was similar to that seen with fababean, with pea 
hulls having a similar composition to those of fababeans (Marquardt et al. 1975).

The addition of different crude enzyme preparations to diets containing Trapper peas tended to reduce feed intake and weight gain (only Energex was significant) but not the feed-to-gain ratio. In contrast, enzyme supplementation improved the feed-to-gain ratio of raw or autoclaved Maple peas (high-tannin variety) but did not affect feed intake or weight gain. These results suggest that enzymes that have a wide range of activities at higher levels of supplementation can improve the utilization of peas by chicks but considering data from studies 1 and 3 , this response appears to be variety dependant. It is conceivable that other enzyme combinations may be more effective as the starch of peas is much less digestible than that of wheat (Longstaff and McNab 1986, 1987).

Dehulling and autoclaving the two pea cultivars produced different responses in the chick. Dehulling improved the feed-to-gain ratio of chicks fed both cultivars of peas while autoclaving only improved the nutritional value of the high-tannin cultivar (Maple). Similarly, both treatments improved APD and $\mathrm{AME}_{\mathrm{n}}$ values for chicks fed Maple but not Trapper peas. These observations suggest that the effect of the high crude fiber content of pea hulls on efficiency of feed utilization can be overcome by dehulling while the effect of tannins and associated phenolic compounds, compounds found in the hulls, on APD and $\mathrm{AME}_{\mathrm{n}}$ values in the tannin-containing cultivar can be eliminated by dehulling or by heat treatment. Previously, Conan and Carre (1989) demonstrated that autoclaving different pea cultivars had a significant improvement on the $\mathrm{AME}_{\mathrm{n}}$ values. They did not, however, indicate if they contained condensed tannins. Similar studies with fababeans showed that condensed tannins greatly decreased APD and $A M E_{n}$ values and that heat treatment and dehulling were effective methods for either inactivating or removing them from the seed (Marquardt and Ward 1979).

In conclusion, dehulling or autoclaving improved the $\mathrm{AME}_{\mathrm{n}}$ and $\mathrm{APD}$ values of tannin-containing peas but not of tannin-free peas and dehulling both types of pea improved the feed-to-gain ratio but not weight gains. Enzyme treatment was only beneficial when added to diets with tannin-containing peas. The performance of chicks fed a corn-pea diet containing up to $48 \%$ pea can be similar to that obtained with a corn-soybean diet.

\section{ACKNOWLEDGMENTS}

The authors wish to thank R. Araneda, H. Stelsovsky and $\mathrm{H}$. Muc for technical assistance and Dr. G. H. Crow for statistical advice and the Manitoba Pulse Growers Association for financial assistance.

Aman, P. and Hesselman, K. 1984. Analysis of starch and other main constituents of cereal grains. Swed. J. Agric. Res. 14: 135-139.

Andrews, R. P. and Baldar, N. A. 1985. Amino acid analysis of feed constituents. Science Tools 32: 44-48.

Association of Official Analytical Chemists. 1984. Official methods of analysis. 14th ed. Association of Official Analytical Chemists. Washington, DC.

Burns, R. E. 1963. Method of tannin analysis for forage crop evaluation. University of Georgia, Agricultural Experimental Station. Tech. Bull. N.S. 32 p. 14.

Campbell, G. L. and Bedford, M. R. 1992. Enzyme applications for monogastric feeds: A review. Can. J. Anim. Sci. 72: 449-466.

Castanon, J. I. and Marquardt, R. R. 1989. Effect of enzyme addition, autoclaved treatment and fermenting on the nutritive value of field beans (V. faba L.). Anim. Feed Sci. Tech. 26: 71-79. Classen, H. L., Campbell, G. L., Rossnagel, B. G., Bhatti, R. and Reichert, R. D. 1985. Studies on the use of hulless barley in chick diets. Deleterious effects and methods of alleviation. Can. J. Anim. Sci. 65: 725-733.

Conan, L. and Carre, B. 1989. Effect of autoclaving on metabolizable energy value of smooth pea seed ( $P$. sativum) in growing chicks. Anim. Feed Sci. Tech. 26: 337-345.

Davidson, J. 1980. The nutritive value of field peas ( $P$. sativum) in an oat-based diet for laying hens. J. Sci. Food Agric. 31: 1055-1058.

Hesselman, K., Elwinger, K., Nilson, M. and Thomke, S. 1981. The effect of $\beta$-glucanase supplementation, stage of ripeness and storage treatment of barley in diets fed to broiler chickens. Poult. Sci. 60: 2664-2671. 
Hirs, C. H. W. 1967. Determination of cystine as cysteic acid. Pages 59-62 in C. H. W. Hirs. ed. Methods in enzymology. Vol. XI. Academic Press, New York, NY.

Institut National de la Recherche Agronomique. 1984. L'alimentation des animaux monogastrics: porcs, lapins, volailles. J. C. Blum. Ed. INRA. Paris, France.

Larbier, M. and Blum, J. C. 1981. Remplacement du tourteau de soja par la farine de viande et des associations proteagineous dans l'alimentation du poulet de chair. Ann Zootech. 30: 335-346.

Longstaff, M. and McNab, J. M. 1986. Influence of site and variety on starch, hemicellulose and cellulose composition and their digestibilities by adult cockerels. Br. Poult. Sci. 27: 435-449.

Longstaff, M. and McNab, J. M. 1987. Digestion of starch and fibre carbohydrates in peas by adult cockerels. Br. Poult. Sci. 28: 261-285.

Marquardt, R. R. 1983. A simple spectrophotometric method for the direct determination of uric acid in avian excreta. Poult. Sci. 62: 2106-2108.

Marquardt, R. R., McKirdy, J. A., Ward, T. and Campbell, L. D. 1975. Amino acid, hemagglutinin and proximate analysis of fababeans (Vicia faba L. var. minor) and fababean fractions. Can. J. Anim. Sci. 55: 421-429.

Marquardt, R. R. and Ward, A. T. 1979. Chick performance affected by autoclave treatment of tannin-containing and tannin-free cultivars of fababeans. Can. J. Anim. Sci. 59: 781-789.

Mascharenhas Ferreira, A., Kerstens, J. and Cast, C. H. 1983. The study of several modifications of the neutral detergent fiber procedure. Anim. Feed Sci. Technol. 9: 19-28.

Moran, E. T., Summers, J. D. and Jones, G. E. 1968. Field peas as a major dietary protein source for the growing chicks and laying hens with emphasis on high temperature steam pelleting as a practical means of improving nutritional values. Can. J. Anim. Sci. 48: 47-55.

National Research Council. 1984. Nutrient requirements of domestic animals. Nutrient requirements of poultry. 8th ed. NAS-NRC, Washington, DC.

Rotter, B. A., Friesen, O. D., Guenter, W. and Marquardt, R. R. 1990. Influence of enzyme supplementation on the bioavailable energy of barley. Poult. Sci. 69: 1174-1181.
Rotter, B. A., Frohlich, A. A., Rotter, R. G. and Marquardt, R. R. 1989. Research note: Estimation of apparent protein digestibility using uric acid-corrected nitrogen values in poultry excreta. Poult. Sci. 68: 327-329.

Saini, H. S. 1988. Legume seed oligosaccharides. Pages 329-344 in J. Huisman, A. F. B. van de Poel, and I. E. Liener, eds. Recent advances of research in antinutritional factors in legume seeds. Pudoc. Wageningen, The Netherlands.

Savage, G. P. 1988. Antinutritive factors in peas. Pages 342-349 in J. Huisman, A. F. B. van de Poel, and I. E. Liener, eds. Recent advances of research in antinutritive factors in legume seeds. Pudoc, Wageningen, The Netherlands.

Savage, G. P. and Deo, S. 1989. The nutritional value of peas ( $P$. sativum). Nutr. Abstr. Rev. A. 59: $66-88$.

Statistical Analysis Systems Institute, Inc. 1986. SAS user's guide: Statistics 1986 Edition. SAS Institute, Inc., Cary, NC.

Suga, Y., Kaway, M., Noguchi, S., Shimura, G. and Samejima, H. 1978. Application of cellulolytic and plant tissue macerating enzyme of Irpex lacteus Fr. as a seed additive enzyme. Agric. Biol. Chem. 42: 782-790.

Trevino, J., Centeno, C., Brenes, A. and Yuste, P. 1990. Effect of dietary oligosaccharides on the digestion of pea starch by growing chicks. Anim. Feed Sci. Technol. 30: 313-319.

Van Soest, P. J. and Wine, R. H. 1967. Use of detergents in the analysis of fibrous feeds. IV. Determination of plant cell wall constituents. J. Assoc. Off. Anal. Chem. 50: 50.

Vogt, H. 1983. Nutritional value of peas in chickens. 4th European Symposium on Poultry Nutrition, Tours, France. pp. 132-140.

Vose, J. R., Basterrechea, M. J., Gorin, P. A. J., Finlayson, A. J. and Young, C. G. 1976. Air classification of field peas and horse bean flour. Chemical studies of starch and protein fractions. Cereal Chem. 53: 928-936.

White, W. B., Bird, H. R., Sunde, M. L., Prentice, N., Burger, W. C. and Marlett, J. A. 1981. The viscosity interaction of barley $\beta$-glucan with Trichoderma viride cellulase in the chick intestine. Poult. Sci. 60: 1043-1048.

Williams, C. H., David, D. I. and Iismaa, $O$. 1962. The determination of chromic oxide in faeces samples by atomic absorption spectrophotometry. J. Agric. Sci. (Camb.) 59: 381-385. 